\author{
ANALISIS MODEL MANAJEMEN KOPERASI DALAM \\ MENINGKATKAN KINERJA KOPERASI \\ Erwin Asidah $^{1}$ \\ Mala Vinuzia ${ }^{2}$ \\ Fakultas Ilmu Sosial dan Politik Universitas Muhammadiyah Mataram \\ erwinasidahumm@gmail.com ${ }^{1}$ \\ $\underline{\text { malavinuzia252@gmail.com }}^{2}$
}

\begin{abstract}
Data on the growth of cooperative business shows that the performance of cooperatives as indicated by the volume of business and net income has decreased during the years 20082010. Various previous studies have shown that the factors that influence the performance of a successful business are entrepreneurship, member participation, and cooperative management. Based on the empirical phenomena found in this research field, the formulation of the research problem formulated here is "How to improve the performance of various business cooperatives in MATARAM CITY." To answer this research problem, an approach with three research variables is used, namely entrepreneurship, member participation, and cooperative management. Testing the effect of each variable was carried out using the Multiple Regression Test on data collection obtained through interviews using a questionnaire to 74 cooperative administrators in the city of Mataram. The results of the regression test of member participation have a significant effect on the performance of the Multi-Business Cooperative in Mataram City, and the management of the cooperative has a significant effect on the performance of the Multi-Business-Owned Cooperative.
\end{abstract}

\title{
ANALISIS MODEL MANAJEMEN KOPERASI DALAM MENINGKATKAN KINERJA KOPERASI
}

\begin{abstract}
ABSTRAK
Data pertumbuhan usaha koperasi menunjukkan bahwa kinerja koperasi yang ditunjukkan oleh volume usaha dan laba bersih mengalami penurunan selama tahun 2008-2010. Berbagai penelitian sebelumnya menunjukkan bahwa faktor-faktor yang mempengaruhi kinerja bisnis yang berhasil adalah kewirausahaan, partisipasi anggota, dan pengurus koperasi. Berdasarkan fenomena empiris yang ditemukan di lapangan penelitian ini maka rumusan masalah penelitian yang dirumuskan disini adalah "Bagaimana cara meningkatkan kinerja Koperasi Berbagai Usaha di KOTA MATARAM" Untuk menjawab masalah penelitian ini digunakan pendekatan dengan tiga variabel penelitian yaitu kewirausahaan, partisipasi anggota, dan pengelolaan koperasi. Pengujian pengaruh masing-masing variabel dilakukan dengan menggunakan Uji Regresi Berganda pada pengumpulan data yang diperoleh melalui wawancara menggunakan kuesioner kepada 74 pengurus koperasi di Kota Mataram. Hasil uji regresi partisipasi anggota berpengaruh signifikan terhadap kinerja Koperasi Aneka Usaha di
\end{abstract}


Kota Mataram, dan pengurus koperasi berpengaruh signifikan terhadap kinerja Koperasi Usaha Milik Berbagai Usaha.

\section{Kata kunci: Kewirausahaan, Kinerja Koperasi}

\section{A. Pendahuluan}

Koperasi adalah badan usaha yang beranggotakan orang-orang atau badan hukum koperasi dengan landasan kegiatan berdasarkan prinsip koperasi sekaligus sebagai gerakan ekonomi rakyat berdasarkan azas kekeluargaan. Koperasi menjunjung tinggi nilai-nilai kebersamaan dan kerja sama antar anggotanya untuk mewujudkan meningkatkan kesejahteraan para anggotanya dan kemakmuran masyarakat. Koperasi, sebagai bagian integral dari pembangunan ekonomi nasional juga harus terus ditingkatkan kemampuan manajerial dan keterampilannya sehingga menjadi badan usaha yang profesional dan tangguh. Dengan pendekatan ini koperasi akan mampu melaksanakan kegiatan usahanya secara efisiensi tanpa harus meninggalkan prinsipprinsip dasarnya. Upaya untuk menjadikan koperasi sebagai badan usaha yang profesional dan tangguh sehingga menjadi akselarator gerakan ekonomi rakyat telah dibuat dengan UU No. 25 tahun 1992 tentang Perkoperasian. Memasuki tahun 2000 koperasi Indonesia didominasi oleh koperasi kredit yang menguasai antara 55\%-60\% dari keseluruhan aset koperasi. Sementara itu dilihat dari populasi koperasi yang terkait dengan program pemerintah hanya sekitar $25 \%$ dari populasi koperasi atau sekitar $35 \%$ dari populasi koperasi aktif. Hingga akhir 2002, posisi koperasi dalam pasar perkreditan mikro menempati tempat kedua setelah Bank Rakyat Indonesia (BRI) unit desa sebesar $46 \%$ dari KSP/USP dengan pangsa sekitar 31\%. Dengan demikian walaupun program pemerintah cukup gencar dan menimbulkan distorsi pada pertumbuhan kemandirian koperasi, tetapi hanya menyentuh sebagian dari populasi koperasi yang ada. Sehingga pada dasarnya masih besar elemen untuk tumbuhnya kemandirian koperasi (Soetrisno, 2003). Berdasarkan data resmi dari Departemen Koperasi dan UKM, sampai dengan bulan November 2007, jumlah koperasi di seluruh Indonesia tercatat sebanyak 149.793 unit lebih, dengan jumlah keanggotaan ada sebanyak 28.100.000 orang. Jumlah itu jika dibanding dengan jumlah koperasi per Desember 1998 mengalami peningkatan sebanyak dua kali lipat. Jumlah koperasi aktif, juga mengalami perkembangan yang cukup menggembirakan. Jumlah koperasi aktif per November 2001, sebanyak 96.180 unit (88,14 persen). Hingga tahun 2004 tercatat 130.730, tetapi yang aktif mencapai 71,50\%, sedangkan yang menjalan Rapat Anggota Tahunan (RAT) hanya 35,42\% koperasi saja. Tahun 2006 tercatat ada 138.411 unit dengan anggota 27.042 .342 orang akan tetapi yang aktif 94.708 unit dan yang tidak aktif sebesar 43.703 unit.

Sedangkan menurut Ketua Umum Dewan Koperasi Indonesia (Dekopin), Adi Sasono, yang diberitakan di Kompas, Kamis, per 31 Mei 2007 terdapat 138.000 koperasi di Indonesia, namun 30 persennya belum aktif. Informasi terakhir dari Triyatna (2009), jumlah koperasi tahun 2007 mencapai 149.793 units, diantaranya 104.999 aktif, atau sekitar 70\% dari jumlah koperasi dan sisanya 44.794 nonaktif. Selama periode 20062007, jumlah koperasi aktif tumbuh 6,1\% sedangkan laju pertumbuhan koperasi tidak aktif sekitar 5,7\%. 57 Corak koperasi Indonesia adalah koperasi dengan skala sangat kecil. Salah satu indikator yang umum digunakan untuk mengukur kinerja koperasi adalah perkembangan volume usaha dan Sisa Hasil Usaha (SHU).

Mengacu pada data perkembangan usaha koperasi, kinerja koperasi yang ditunjukkan oleh volume usaha dan SHU mengalami penurunan selama periode tahun 
2008-2010. Hashim, Wafa, dan Sulaiman (2000) mengemukakan bahwa salah satu faktor yang bepengaruh terhadap keberhasilan kinerja usaha adalah faktor kewirausahaan. Kotey (1997) mengatakan bahwa wirausaha yang mempunyai nilai kewirausahaan dan mengadopsi strategi proaktif akan memperoleh kinerja usaha yang tinggi sedangkan wirausaha yang konservatif dan mengadopsi strategi reaktif memperoleh kinerja rendah. Senada dengan kedua pendapat tersebut, Lee (2000) menyatakan, kesuksesan usaha sangat tergantung pada peranan wirausahawan itu sendiri dan dalam kewirausahaan, faktor manusia memainkan peranan penting di samping faktor lainnya (Shane, 2003). Selain itu, Navanhandi (2003), Solichin (2005), Herri (2003), dan Yonggui (2003) mengemukakan kinerja suatu bisnis diperngaruhi oleh karakteristik kewirausahaan manajer / pemilik. Selain itu, banyak pakar yang menyatakan bahwa kunci keberhasilan koperasi antara lain terletak pada partisipasi anggota (Muslimin Nasution, 1987 dan Syamsuri SA, 1986). Sehingga dapat dikatakan bahwa partisipasi dalam koperasi seperti jantungnya tubuh manusia, karena dalam koperasi anggota berperan ganda (dual identity) yaitu sebagai pemilik dan pengguna, disinilah letak keunikan badan usaha koperasi karena pemilik usaha merangkap sebagai pengguna jasa, karena kedua sifat ini menyebabkan koperasi lebih banyak menuntut partisipasi dari anggota untuk mengembangkan usaha yang telah didirikan bersama untuk mencapai tujuannya (A Jajang W Mahri, 2010). Selain faktor sikap wirausaha manajer dan partisipasi anggota, keberhasilan kinerja koperasi juga ditentukan oleh faktor manajemen koperasi. Menurut Arman D Hutasuhut (2001), koperasi merupakan lembaga yang harus dikelola sebagaimana layaknya lembaga bisnis. Di dalam sebuah lembaga bisnis diperlukan sebuah pengelolaan yang efektif dan efisien yang dikenal dengan manajemen. Demikian juga dalam badan usaha koperasi, manajemen merupakan satu hak yang harus ada demi terwujudnya tujuan yang diharapkan.

\section{B. METODE PENELITIAN}

Populasi

Populasi dalam penelitian ini adalah 10 Koperasi yang berada di Kota Mataram.

Sampel

Sampel adalah sebagian dari populasi yang memiliki karakteristik yang relatif sama dan dianggap bisa mewakili populasi (Singarimbun, 1991).

Untuk menentukan jumlah sampel yang representatif digunakan rumus perhitungan sampel dari Tabanick dan Fidel (1996) yaitu Sampel (n) $=($ Jumlah variabel independen $\times 8)+50$ Mengacu pada rumus penentuan jumlah sampel di atas maka jumlah sampel minimal untuk penelitian ini adalah sebagai berikut: Sampel $(n)=(3 \times 8)$ $+50=74$ Dengan demikian jumlah sampel yang digunakan dalam penelitian ini adalah 74 manajer Koperasi di Kota Bima. Teknik pengambilan sampel yang digunakan dalam penelitian ini dilakukan dengan metode simple random sampling dimana masing masing anggota populasi memiliki kesempatan yang sama untuk terpilih menjadi sampel.

Definisi Operasional dan Pengukuran Variabel Penelitian Variabel Jiwa Kewirausahaan Pemimpin (X1)

Jiwa Kewirausahaan Pemimpin adalah semangat, sikap, perilaku dan kemampuan seseorang dalam menangani usaha dan atau kegiatan yang mengarah pada upaya mencari, menciptakan, menerapkan cara kerja, teknologi dan produk baru dengan meningkatkan efisiensi dalam rangka memberikan pelayanan yang lebih baik dan atau memperoleh keuntungan yang besar yang dimiliki oleh manajer (Geoffrey G. Meredith). 
Variabel Jiwa Kewirausahaan Pemimpin koperasi diukur dengan menggunakan beberapa indikator yang dikembangkan dari Drucker (1988) yang meliputi sikap mental positif dalam berusaha secara koperatif (X1_1), prakarsa inovatif (X1_2), keberanian mengambil resiko (X1_3), berpegang pada prinsip identitas koperasi (X1_4).

Variabel Gaya Partisipasi Para Anggota (X2)

Partisipasi anggota merupakan perwujudan dari keikutsertaan anggota dalam kegiatan-kegiatan yang dilaksanakan oleh koperasi untuk mencapai tujuan yang telah ditetapkan (Ropke, 2003). Variabel partisipasi anggota diukur dengan menggunakan indikator yang dikembangkan dari Ropke (2003), yang meliputi partisipasi anggota dalam mengkontribusikan atau menggerakan sumber-sumber dayanya (X2_1), partisipasi anggota dalam mengambil keputusan (X2_2), dan partisipasi anggota dalam menikmati manfaat (X2_3).

Variabel Model Manajemen Koperasi (X3) Manajemen koperasi adalah kelembagaan koperasi yang melibatkan empat unsur yaitu: anggota, pengurus, manajer, dan karyawan (Hendrojogi, 1997). Pengukuran variabel manajemen koperasi dilakukan dengan menggunakan indikator dari Sitio dan Tamba (2001) yang meliputi rapat anggota (X3_1), pengurus (X3_2), pengawas (X3_3), dan pengelola (X3_4).

Variabel Kinerja Koperasi (Y)

Kinerja koperasi diukur dengan menggunakan Sisa Hasil Usaha (SHU), yaitu pendapatan koperasi yang diperoleh dalam satu tahun buku dikurangi dengan biaya, penyusutan, dan kewajiban lainnya termasuk pajak dalam tahun buku yang bersangkutan (Undang-undang Nomor 25 Tahun 1992 tentang Perkoperasian Pasal 45). Variabel kinerja koperasi diukur dengan menggunakan Sisa Hasil Usaha (SHU) Koperasi yang dicapai pada tahun terakhir.

\section{Analisis dan Pembahasan}

Untuk mengumpulkan data penelitian, kuesioner dipilih sebagai metode pengumpulan data dalam penelitian ini. Kuesioner adalah daftar pertanyaan tertulis yang telah dirumuskan sebelumnya yang akan dijawab oleh responden. Kuesioner dipilih karena merupakan suatu mekanisme pengumpulan data yang efisien untuk mengetahui dengan tepat apa yang diperlukan dan bagaimana mengukur variabel penelitian (Sekarang, 2006). Tipe pertanyaan dalam kuesioner adalah pertanyaan tertutup dimana responden diminta untuk membuat pilihan diantara serangkaian alternatif yang diberikan oleh peneliti (Sekarang, 2006). Skala data jawaban responden atas pertanyaan penelitian dengan menggunakan Skala Likert yang menghasilkan jawaban pada rentang $1-5$.

Mengacu pada hasil pengujian pengaruh sikap wirausaha manajer, partisipasi anggota, dan manajemen koperasi terhadap kinerja koperasi yang diukur melalui SHU maka dapat dilakukan pengujian hipotesis dengan kriteria sebagai berikut:

a. $\mathrm{H} 0$ ditolak dan Ha diterima, jika nilai t hitung $>\mathrm{t}$ tabel atau nilai signifikansi $<0,05$ maka dapat disimpulkan bahwa variabel independen terbukti secara statistik berpengaruh terhadap variabel dependen

b. H0 diterima dan Ha ditolak, jika nilai $\mathrm{t}$ hitung $<\mathrm{t}$ tabel atau nilai signifikansi $>0,05$ maka dapat disimpulkan bahwa variabel independen tidak terbukti secara statistik berpengaruh terhadap variabel dependen Berikut hasil pengujian hipotesis untuk masingmasing variabel bebas:

1. Hasil pengujian pengaruh variabel sikap wirausaha manajer terhadap kinerja koperasi menghasilkan nilai Koefisien Regresi sebesar 0,195 dengan nilai t hitung sebesar 2,798 dan nilai Signifikansi sebesar 0,007. Oleh karena nilai signifikansi lebih kecil dari 0,05 
maka dapat disimpulkan bahwa $\mathrm{H} 0$ ditolak dan Ha diterima, artinya hipotesis pertama yang menyatakan "Jiwa kewirausahaan Pemimpin berpengaruh positif terhadap kinerja usaha koperasi" dapat diterima.

2. Hasil pengujian pengaruh variabel partisipasi anggota terhadap kinerja koperasi menghasilkan nilai Koefisien Regresi sebesar 0,135 dengan nilai t hitung sebesar 2,178 dan nilai Signifikansi sebesar 0,033. Oleh karena nilai signifikansi lebih kecil dari 0,05 maka dapat disimpulkan bahwa $\mathrm{H} 0$ ditolak dan Ha diterima, artinya hipotesis kedua yang menyatakan "Gaya partisipasi para anggota koperasi berpengaruh positif terhadap kinerja usaha koperasi" dapat diterima.

3. Hasil pengujian pengaruh variabel manajemen koperasi terhadap kinerja koperasi menghasilkan nilai Koefisien Regresi sebesar 0,672 dengan nilai t hitung sebesar 7,981 dan nilai Signifikansi sebesar 0,000. Oleh karena nilai signifikansi lebih kecil dari 0,05 maka dapat disimpulkan bahwa $\mathrm{H} 0$ ditolak dan Ha diterima, artinya hipotesis ketiga yang menyatakan "Model manajemen koperasi berpengaruh positif terhadap kinerja usaha koperasi" dapat diterima. Mengacu pada hasil pengujian hipotesis di atas maka dapat dikembangkan persamaan regresi sebagai berikut: $\mathrm{Y}=0,195 \mathrm{X} 1+0,135 \mathrm{X} 2+0,672 \mathrm{X} 3$ Persamaan regresi tersebut dapat dijelaskan sebagai berikut:

1. $\beta 1=0,195 \diamond \beta 1$ bertanda positif yang berarti bahwa jika sikap wirausaha manajer meningkat maka kinerja koperasi juga akan ikut meningkat.

2. $\beta 2=0,135 \diamond \beta 2$ bertanda positif yang berarti bahwa jika partisipasi anggota meningkat maka kinerja koperasi juga akan ikut meningkat.

3. $\beta 3=0,672 \diamond \beta 3$ bertanda positif yang berarti bahwa jika manajemen koperasi diperbaiki maka kinerja koperasi juga akan ikut meningkat. Koefisien Determinasi Koefisien determinasi ( $\mathrm{R} 2$ ) mengukur seberapa jauh kemampuan model dalam menerangkan variasi variabel dependen.

Nilai Koefisien Determinasi Nilai Koefisien Determinasi yang dihasilkan pada pengujian pengaruh sikap wirausaha manajer, partisipasi anggota, dan manajemen koperasi terhadap kinerja koperasi adalah sebesar 0,860 atau sebesar $86 \%$, artinya variasi atau perubahan yang terjadi pada kinerja koperasi, 86\%-nya mampu dijelaskan oleh Sumber: Data Primer yang Diolah, 2011 sikap wirausaha manajer, partisipasi anggota, dan manajemen koperasi sedangkan sisanya dijelaskan oleh variabel lain yang tidak diteliti dalam penelitian ini.

\section{Kesimpulan}

Dari hasil penelitian dapat disimpulkan bahwa penyimpangan dan membuat pengurus atau manajemen lebih bertanggung jawab. Para anggota koperasi memiliki hak dan kesempatan serta termotivasi dan sanggup untuk berpartisipasi dalam mengambil keputusan mengenai tujuan yang hendak dicapai, berpartisipasi dalam pemupukan modal dan partisipasi dalam pemanfaatan pelayanan yang diberikan koperasi untuk mewujudkan tujuan koperasi yang telah ditentukan.

Pengujian pada variabel manajemen koperasi dan kinerja koperasi secara statistik membuktikan bahwa manajemen koperasi berpengaruh positif terhadap kinerja koperasi. Sistem manajemen di lembaga koperasi harus mengarah kepada manajemen partisipatif yang di dalamnya terdapat kebersamaan, keterbukaan, sehingga setiap anggota koperasi baik yang turut dalam pengelolaan (kepengurusan usaha) ataupun yang di luar kepengurusan (angota biasa), memiliki rasa tanggung jawab bersama dalam organisasi koperasi. Manajemen koperasi pada dasarnya dapat ditelaah dan tiga sudut pandang, yaitu organisasi, proses, dan gaya. Dari sudut pandang organisasi, manajemen koperasi 
pada prinsipnya terbentuk dan tiga unsur: anggota, pengurus, dan karyawan. Dapat dibedakan struktur atau alat perlengkapan organisasi yang sepintas adalah sama yaitu: Rapat Anggota, Pengurus, dan Pengawas. Untuk itu, hendaknya dibedakan antara fungsi organisasi dengan fungsi manajemen. Unsur Pengawas seperti yang terdapat pada alat perlengkapan organisasi koperasi, pada hakekatnya adalah merupakan perpanjangan tangan dan anggota, untuk mendampingi Pengurus dalam melakukan fungsi kontrol sehari-hari terhadap jalannya roda organisasi dan usaha koperasi. Dan sudut pandang proses, manajemen koperasi lebih mengutamakan demokrasi dalam pengambilan keputusan. Istilah satu orang satu suara (one man one vote) sudah mendarah daging dalam organisasi koperasi.

Karena itu, manajemen koperasi ini sering dipandang kurang efisien, kurang efektif, dan sangat mahal. Terakhir, ditinjau dan sudut pandang gaya manajemen (management style), manajemen koperasi menganut gaya partisipatif (participation management), di mana posisi anggota ditempatkan sebagai subjek dan manajemen yang aktif dalam mengendalikan manajemen perusahaannya. Badan usaha koperasi di Indonesia memiliki manajemen koperasi yang dirunut berdasarkan perangkat organisasi koperasi, yaitu: Rapat anggota, pengurus, pengawas, dan pengelola. Telah diuraikan sebelumnya bahwa, watak manajemen koperasi ialah gaya manajemen partisipatif. Pola umum manajemen koperasi yang partisipatif tersebut menggambarkan adanya interaksi antar unsur manajemen koperasi. Terdapat pembagian tugas (job description) pada masing-masing unsur. Demikian pula setiap unsur manajemen mempunyai lingkup keputusan (decision area) yang berbeda, kendatipun masih ada lingkup keputusan yang dilakukan secara bersama (shared decision areas) Adapun lingkup keputusan masingmasing unsur manajemen koperasi adalah sebagai berikut:

a. Rapat Anggota Tahunan merupakan pemegang kuasa tertinggi dalam menetapkan kebijakan umum di bidang organisasi, manajemen, dan usaha koperasi.

b. Pengurus dipilih dan diberhentikan oleh rapat anggota. Dengan demikian, Pengurus dapat dikatakan sebagai pemegang kuasa Rapat Anggota dalam mengoperasionalkan kebijakan kebijakan strategis yang ditetapkan. Penguruslah yang mewujudkan arah kebijakan strategis yang menyangkut organisasi maupun usaha.

c. Pengawas mewakili anggota untuk melakukan pengawasan terhadap pelaksanaan kebijakan yang dilaksanakan oleh Pengurus. Pengawas dipilih dan diberhentikan oleh Rapat Anggota.

d. Pengelola adalah tim manajemen yang diangkat dan diberhentikan oleh Pengurus, untuk melaksanakan teknis operasional di bidang usaha. Hubungan Pengelola usaha (managing director) dengan pengurus koperasi adalah hubungan kerja atas dasar perikatan dalam bentuk perjanjian atau kontrak kerja.

\section{Daftar Pustaka}

A Jajang W Mahri (2010), Pelayanan dan Manfaat Koperasi, Serta Pengaruhnya terhadap Partisipasi Anggota. Adnan Hakim (2010), Karakteristik Kewirausahaan, Lingkungan Bisnis, dan Kapabilitas Organisasi: Pengaruhnya terhadap Strategi Bisnis dan Kinerja Usaha (Kajian pada Manajemen, 8 (1), p. 11-23.

Amries Rusli Tanjung (2008), Pengaruh Praktik Manajemen Stratejik terhadap Kinerja Koperasi pada KPRI Propinsi Riau, Jurnal Aplikasi Manajemen, 6 (1), p. 169-174. Annisa Aini dan Achma Hendra Setiawan (2006), Analisis Faktor-Faktor yang Mempengaruhi Partisipasi Anggota Koperasi Serba Usaha (KSU) Unit Usaha Simpan 
Pinjam (USP) Karyawan Pemerintah Daerah Kota Semarang, Dinamika Pembangunan, 3 (2), p. 184- 195.

Arman D Hutasuhut (2001), Manajemen Koperasi Menuju Kewirausahaan Koperasi, Jurnal Ilmiah Manajemen dan Bisnis, 1 (1), p. 1-11. Arman D Hutasuhut (2001), Manajemen Koperasi Menuju Kewirausahaan Koperasi, Jurnal Ilmiah Manajemen dan Bisnis, 1 (1), p. 1-11.

Budi Wicaksongko (2000), Analisis Faktor-Faktor yang Berpengaruh terhadap Kinerja Koperasi di Kabupaten Karanganyar Tahun 1999, Tesis, Universitas Diponegoro, Semarang. Drucker, PF (1985), Innovation and Entrepreneurship, London: Heinemann.

Geoffrey G Meredith et al (2000), Kewirausahaan: Teori dan Praktek, Jakarta: Pusaka Binaman Pressindo. Hadhikusuma, RT Sutantya Rahardja (2001), Hukum Koperasi Indonesia, Jakarta: Raja Grafindo Persada.

Hendrojogi, (1999), Koperasi - Azas-azas, Teori dan Praktek, Rajawali Pers., Jakarta. Herri dan SA Wafa (2003), The Personality, Background and Network Activities on Venture Growth, Journal of Management Studies, 38 (4), p. 583.

Made Antara (2010), Kinerja Influence of Internal and Koperasi Unit Desa di Provinsi External Factors to The Bali: Pendekatan Structural Performance of Indonesian Small and Medium Entreprises.

IDKR Ardiana, IA Brahmayanti, dan Subaedi (2010), Kompetensi SDM UKM dan Pengaruhnya terhadap Kinerja UKM di Surabaya, Jurnal Manajemen dan Kewirausahaan, 12 (1), p. 42-55.

Imam Ghozali (2001), Aplikasi Analisis Multivariate dengan Program SPSS, Semarang: BP Undip. Kartib Bayu (2010), Pengaruh Sikap Wirausaha Manajer dan Partisipasi Anggota terhadap Implementasi Strategi Pemasaran Produk dan Implikasinya terhadap Kinerja Usaha Koperasi, Majalah Ilmiah UNIKOM, 8 (2), p. 165- 174.

Kotey, B dan GG Meredith (1997), Relationship Among Owner/Manager Personal Values, Business Strategies, and Enterprise Performance, Journal of Small Business Management, 35 (2). Lee, DY., EWK Tsang (2000), The Effect of Entrepreneura Personality, Background and Network Activities on Venture Growth, Journal of Management Studies, 38 (4), p. 583. 